\title{
Chest Pain and Its Recurrence in Pediatric Population: A Large Cohort Study
}

\section{Çocukluk Çağında Göğüs Ağrısı ve Tekrarlama Sıklığı: Geniş Bir Toplum Çalışması}

\author{
Esma Keleş Alp', @Hayrullah Alp² \\ 'Dr. Ali Kemal Belviranlı Obstetrics and Children's Hospital, Department of Pediatrics, Konya, Turkey \\ ${ }^{2}$ KTO Karatay University, Medical Faculty, Department of Pediatrics, Konya, Turkey
}

\begin{abstract}
Introduction: Chest pain is a common complaint in children. In this retrospective study we investigated the clinical and etiological characteristics and the recurrence rates of chest pain in a large cohort of patients.

Material and Method: This study enrolled children under the age of 18 years who admitted to our pediatrics and pediatric cardiology departments with the chief complaint of chest pain. The medical files and laboratory data of patients with chest pain were retrospectively reviewed.

Results: Among 503 patients with chest pain, 346 (68.7\%) cases were referred to pediatric cardiology department because of a suspicious of a cardiac chest pain. Non-cardiac chest pain accounted for $95.2 \%$ (478 patients) and cardiac chest pain accounted for $4.8 \%$ (25 patients). A total of 23 (92\%) patients in cardiac chest pain group and 212 (44.3\%) patients in non-cardiac group had recurrent chest pain. Recurrent chest pain was commonly detected in cardiac chest pain, respiratory, gastrointestinal and psychological disorders.

Discussion and Conclusion: In this study, the most common etiologies of chest pain in children were idiopathic chest pain and musculoskeletal disorders. Also, our results showed that chest pain is commonly recurrent and cardiac causes of chest pain are very rare in children. Unnecessary referrals should be reduced with a careful history and physical examination.
\end{abstract}

Keywords: Chest pain, children, recurrence, cardiac related, referrals
Öz

Amaç: Göğüs ağrısı çocuklarda yaygın görülen bir şikâyettir. Bu retrospektif çalışmada pediatri bölümüne başvuran ve pediatrik kardiyoloji bölümüne sevk edilen geniş bir hasta grubunda göğüs ağrııının klinik ve etiyolojik özellikleri ile tekrarlama oranlarını araştırdık.

Gereç ve Yöntem: Bu çalışmaya pediatri bölümümüze başvuran ve göğüs ağrısı şikayeti ile pediatrik kardiyoloji bölümüne sevk edilen 18 yaşın altındaki çocuklar dâhil edildi. Göğüs ağrısı olan hastaların tıbbi dosyaları ve laboratuar verileri retrospektif olarak incelendi.

Bulgular:Göğüs ağrısı olan 503 hastadan 346'sı (\% 68.7) kardiyak göğüs ağıısı şüphesi nedeniyle pediatrik kardiyoloji bölümüne sevk edilmişti. Kardiyak nedenlerle ilişkili olmayan göğüs ağııs \%95.2 (478 hasta) kardiyak nedenlerle ilişkili göğüs ağrıı \%4.8 (25 hasta) oranlarında idi. Kardiyak nedenlerle ilişkili göğüs ağrısı grubunda 23 hasta (\%92) ve kardiyak olmayan grupta 212 hastada (\% 44.3) tekrarlayan göğüs ağrıs vardı. Tekrarlayan göğüs ağrısı, kardiyak nedenlerle ilişkili göğüs ağrısı, solunum, gastrointestinal ve psikolojik bozukluklarda yaygın olarak saptandı.

Sonuç ve Tartışma: Bu çalışmada, çocuklarda göğüs ağrısının en sık etiyolojiknedeniidiyopatikgöğüs ağrısı vekas-iskelet sistemi hastalıkları olarak bulunmuştur. Ayrıca, bizim sonuçlarımız çocuklarda göğüs ağrısının sık tekrarladığını ve göğüs ağrısının kardiyak nedenlerinin çocuklarda çok nadir olduğunu göstermiştir. Sonuç olarak, dikkatli bir öykü ve fizik muayene ile gereksiz sevk ve yönlendirmeler azaltılabilir.

Anahtar kelimeler: Göğüs ağrısı, çocuklar, tekrarlama, kalple ilişkili, sevkler

Corresponding (İletişim): Esma Keleş Alp, Dr. Ali Kemal Belviranlı Obstetrics and Children's Hospital, Department of Pediatrics, Division of Pediatric Cardiology, 42285, Konya, Turkey

E-mail (E-posta): esmaalp@hotmail.com

Received (Geliş Tarihi): 08.09.2020 Accepted (Kabul Tarihi): 26.11.2020 


\section{INTRODUCTION}

Chest pain is a common complaint in children admitted to the pediatrics, pediatric cardiology and pediatric emergency departments. ${ }^{[1]}$ Also; it threatens life and has an effect on daily life with accounts for $0.3-0.6 \%$ of all chest pain accesses. ${ }^{[2]}$ On the other hand, it is one of the most common reasons for referral to the pediatric cardiologist being second only to heart murmur. ${ }^{[3]}$ Unlike children, chest pain in the adult population is commonly associated with cardiac disorders and sudden death. Dramatic media accounts of sudden deaths in young athletes have focused attention on chest pain as a sign of severe heart disease. However, fatal heart disease is extremely rare in the pediatric population and families seek reassurance when they bring their child to the pediatrics and pediatric cardiology departments or a specialist with a complaint of chest pain. ${ }^{[4,5]}$

Although cardiac disease rarely presents as chest pain in pediatric population, every patient should be evaluated to rule out significant underlying disease with history and physical examination being the first steps in diagnosing the cause of such pain in most cases.

Definitively ruling out cardiac disease in children can be more challenging because most young children are not able to accurately describe or localize their pain. Also, followup studies revealed that $43 \%$ of patients still experienced chest pain at 6 months and $16 \%$ of children with chest pain had more than one visit to the emergency department with the same complaint. ${ }^{[1,6]}$ This may prompt further testing, leading to high resource utilization for chest pain evaluation. However, a cardiac etiology is found only in a small minority of cases, reported from 0 to $10 \%$ in most of the previous studies. ${ }^{[1-8]}$ Because of the potential association with several complex anatomic malformations that may be life threatening and high costs associated with chest pain, there is wide practice variation in the outpatient evaluation of these patients, stimulating efforts to create standardized assessment algorithms. ${ }^{[9-11]}$

The primary objective of this study was to investigate the clinical and etiological characteristics and the recurrence of chest pain in a large cohort of patients admitted to pediatrics department and that referred to pediatric cardiology department. The secondary aim was to examine the occurrence of significant cardiac disease in this population.

\section{MATERIAL AND METHOD}

\section{Study population}

This study enrolled children under the age of 18 years who admitted to our pediatrics department and that referred to pediatric cardiology department with the chief complaint of chest pain over a period of 2.5 years (January, 2017-August, 2019). Information to determine general demographics (ages, sex, weight, height, body mass index, family history), clinical presentation, recurrence of chest pain, associated symptoms, disposition, hospital course, medications and final diagnoses were retrospectively reviewed.

All children underwent complete physical examination, including weight and height measurements. The body mass index was calculated as weight (in kilograms) divided by height (in meters) squared. Children were defined as obese if they had a body mass index greater than or equal to $95^{\text {th }}$ percentile, and overweight if they had a body mass index between $85^{\text {th }}$ and $94^{\text {th }}$ percentile for age and gender based on the standards of the Centers for Disease Control and Prevention. ${ }^{[12]}$ Blood pressure was measured with a standard mercury sphygmomanometer after a 10-minute rest. Abnormalities detected on physical examination, which were considered pertinent positives, included tenderness on palpation over the chondrosternal or costochondral junction, swelling at the chondrosternal junction, murmur, click, gallop, pericardial rub, abnormal second heart sound, distant heart sounds, hepatomegaly, decreased femoral or peripheral pulses, peripheral edema, painful or swollen extremities, and tachypnea. Also, the following studies were performed by a pediatrist and pediatric cardiologist: complete blood count in all patients; fasting total cholesterol, high-density lipoprotein cholesterol, low-density lipoprotein cholesterol, and triglycerides levels in overweight and obese children and children with a family history of premature cardiovascular disease; electrocardiogram, chest X-ray. Additionally, if necessary 24-hour electrocardiogram monitoring and/ or exercise stress tests were performed by the pediatric cardiologist. Electrocardiograms were performed on all the patients with chest pain while echocardiograms were performed on the patients who were referred to pediatric cardiology department. Also, if necessary the patients were referred to pediatric gastroenterology, endocrinology and psychiatry departments for final diagnoses. The recurrence time course was defined as more than one attack during a day period or more than one attack during a week period or more than one attack during a month period.

All the medical records were reviewed by a pediatrician and by a pediatric cardiologist, and children were categorized as affected by cardiac or non-cardiac chest pain. The study was approved by the local ethics committee. (T.C. Ministry Health Konya Provincial Health Directorate Dr. Ali Kemal Belviranli Obstetrics And Pediatrics Hospital date 2020 numbered 99980113-903.99)

\section{Echocardiographic study}

Echocardiographic investigations were performed using Philips Affiniti 50 (Philips Healthcare, Andover, Netherlands) with $5.0 \mathrm{MHz}$ transducers in our pediatric cardiology echocardiography laboratory by the same observer. A full echocardiography including conventional Doppler, color images, and M-mode measurements was performed. Echocardiograms were recorded on a flash drive for repeated evaluation. All measurements were performed according to the American Society of Echocardiography. ${ }^{[13]}$ 


\section{Statistical analyses}

Descriptive statistics were calculated using counts, frequencies, medians, and interquartile ranges for patient demographics and sedation procedure characteristics. Categorical data were presented as frequencies (\%) and analyzed using Chi-square test. Statistical significance was inferred at $p<0.05$. Statistical analyses were done using SPSS for Windows Version 17.0 software (Chicago, IL, USA).

\section{RESULTS}

During the study period, a total of 13,741 patients admitted to pediatrics department and among them 503 patients had a complaint of chest pain. Among these 503 patients with chest pain, $346(68.7 \%)$ cases were referred to pediatric cardiology department because of a suspicious of a cardiac chest pain (Figure 1). The mean age of the cases was $11.1 \pm 3.5$ years (4-17 years) and 225 (45\%) were girls while 278 (55\%) patients were boys in the study population. The mean age of the girls was $10.5 \pm 2.7$ years with a median of 11 years and a range of 4-17 years and the mean age of the boys was $11.3 \pm 2.1$ years with a median of 11 years and a range of 4-16 years. Also, recurrent chest pain was determined in a total of 235 (46.7\%) patients.

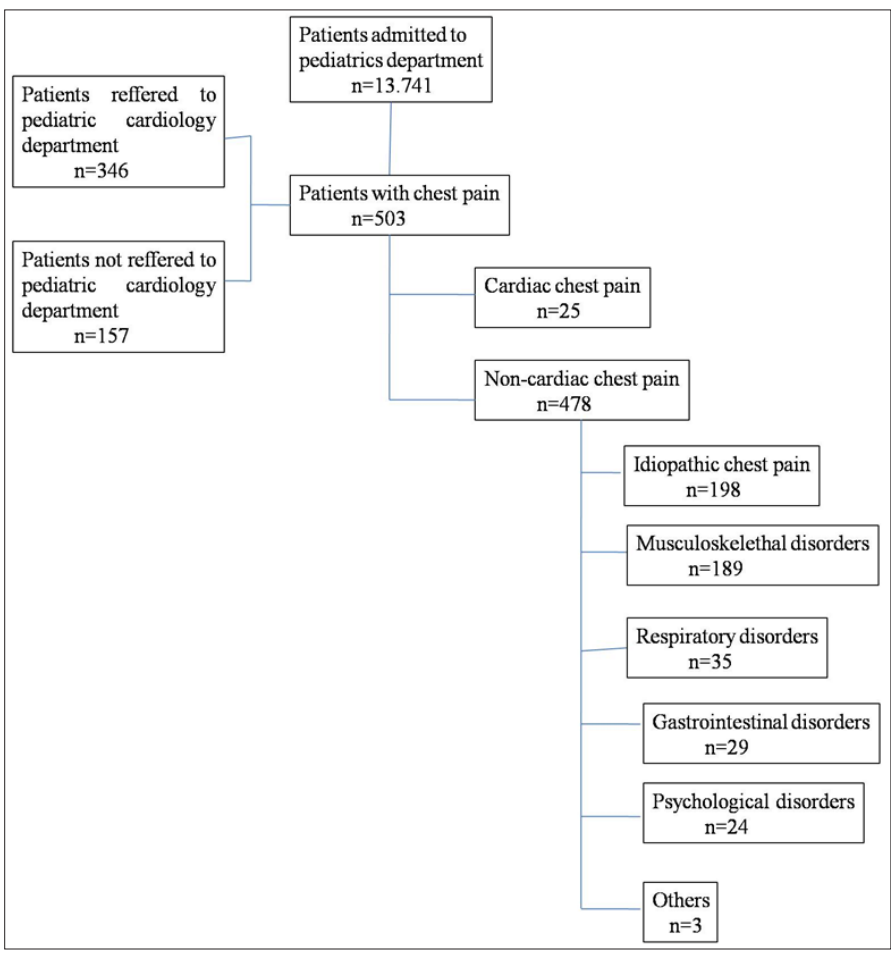

Figure 1. The number of referred patients from pediatric department to pediatric cardiology department and diagnoses for patients with cardiac and non-cardiac chest pain.

Non-cardiac chest pain accounted for $95.2 \%$ (478 patients) and cardiac chest pain accounted for $4.8 \%$ (25 patients). The diagnoses for patients with cardiac and non-cardiac chest pain and related demographic parameters are illustrated in Table 1. There was no statistical difference for mean age (11.68 \pm 4.05 vs. 11.04 $\pm 3.47, p>0.05)$, gender $(p>0.05)$, weight $(38.3 \pm 11.2$ vs. $35.6 \pm 9.2, p>0.05)$, height $(137.5 \pm 14.3$ vs. $139.1 \pm 13.9, p>0.05)$, body mass index $(15.23 \pm 3.2$ vs. $16.35 \pm 3.8, p>0.05)$, systolic blood pressure (95.5 \pm 7.8 vs. $97.1 \pm 5.6 \mathrm{mmHg}, p>0.05)$, chest pain recurrence with effort $(p>0.05)$ or at rest $(p>0.05)$ and hospitalization $(p=0.06)$ between the patients with cardiac and non-cardiac chest pains. On the other hand, non-cardiac chest pain group had the higher percentages (55.6\%, 266 patients) for chest pain without recurrence $(p<0.001)$. Also, $48 \%$ of patients in cardiac chest pain group and $21.1 \%$ of patients in noncardiac chest pain group had more than one visit to our pediatrics and pediatric cardiology departments with the same complaint and this achieved statistical significance $(p=0.03)$. Additionally, non-steroidal anti-inflammatory drug therapy was required for one patient with viral pericarditis in cardiac chest pain group while 149 patients were given non-steroidal anti-inflammatory drugs in non-cardiac chest pain group $(p=0.02)$.

\section{Table 1. Demographic data of patients with cardiac and non-cardiac chest} pain

\begin{tabular}{lccc} 
& $\begin{array}{c}\text { Cardiac chest } \\
\text { pain N:25 }\end{array}$ & $\begin{array}{c}\text { Non-cardiac chest } \\
\text { pain N:478 }\end{array}$ & P value \\
\hline Median age & $11.68 \pm 4.05$ & $11.04 \pm 3.47$ & $>0.05$ \\
$\begin{array}{l}\text { Gender } \\
\quad \text { Male }\end{array}$ & $11(44 \%)$ & $267(55.9 \%)$ & $>0.05$ \\
$\quad$ Female & $14(56 \%)$ & $211(44.1 \%)$ & $>0.05$ \\
Weight $(\mathrm{kg})$ & $38.3 \pm 11.2$ & $35.6 \pm 9.2$ & $>0.05$ \\
Height $(\mathrm{cm})$ & $137.5 \pm 14.3$ & $139.1 \pm 13.9$ & $>0.05$ \\
$\begin{array}{l}\text { Body mass index } \\
\text { (kg/m } \text { ( }^{2} \text { ) }\end{array}$ & $15.23 \pm 3.2$ & $16.35 \pm 3.8$ & \\
$\begin{array}{l}\text { Systolic blood } \\
\text { pressure }\end{array}$ & $95.5 \pm 7.8$ & $97.1 \pm 5.6$ & $>0.05$ \\
Recurrence & & & \\
$\quad$ With exercise & $4(17.4 \%)$ & $35(16.5 \%)$ & $>0.05$ \\
$\quad$ At rest & $19(82.6 \%)$ & $177(83.5 \%)$ & $<0.001$ \\
Without recurrence & $2(8 \%)$ & $266(55.6 \%)$ & 0.03 \\
Recurrent visits & $12(48 \%)$ & $101(21.1 \%)$ & 0.06 \\
Hospitalization & $1(4 \%)$ & $31(6.4 \%)$ & 0.02 \\
Medical therapy & $1(4 \%)$ & $149(31.1 \%)$ & \\
\hline
\end{tabular}

In all the patients, 37 patients (7.3\%) in non-cardiac chest pain group had obesity and 21 patients (4.1\%) were overweight. However, no patient was diagnosed as obese or overweight in cardiac chest pain group.

Table 2 shows the etiology of chest pain in patients. Mitral valve prolapse, hypertrophic cardiomyopathy, bicuspid aortic valve and aortic stenosis, pulmonary artery hypertension and pericarditis were the causes of cardiac chest pain. Idiopathic chest pain and musculoskeletal disorders were the most common diagnosis (39.4\% and $37.6 \%$ ) in the study population. Respiratory, gastrointestinal and psychological disorders are rare causes (7\%, 5.8\% and $4.8 \%$, respectively). Also, among all the patients with psychological disorders, generalised 
anxiety disorders (32.3\%) were the most common form and diagnosed in 11 boy patients which was more common than girls. Of the 189 patients who had musculoskeletal disorders, chostochondritis was the major etiology and was most common in boys. Additionally, severe cough and gastroesophageal reflux were the most common reasons for respiratory and gastrointestinal disorders, respectively. On the other hand, girls had severe cough than the boys in noncardiac chest pain group. Owing to breast pain, two patients had chest pain due to gynaecomastia. Also, one patient was diagnosed Familial Mediterranean Fever and he was treated with colchicine. Additionally, cardiac-related chest pain was more common in girls, whereas non-cardiac related chest pain was more common in boys.

Table 3 shows the recurrence in chest pain. A total of 23 (92\%) patients in cardiac chest pain group and 212 (44.3\%) patients in non-cardiac group had recurrent chest pain. Recurrent chest pain was commonly detected in cardiac chest pain, respiratory, gastrointestinal and psychological disorders. Also, recurrent chest pain was more common in girls in the cardiac chest pain group. On the other hand, recurrence was more common in boys who had idiopathic chest pain, musculoskeletal, gastrointestinal and psychological disorders.

\section{DISCUSSION}

Chest pain is a common referral complaint in children and in some patients can become recurrent and severe, interfering significantly with the daily life activities. In recent years, news and media reports on sudden deaths in athletes have created concern among both families and physicians. Primary care and emergency department physicians may be fearful of missing cardiac pathology and assuming responsibility for clearing athletes to participate in sports. In this retrospective study, we reported demographic and clinical characteristics, as well as causes of chest pain and its recurrence in children referred to our pediatric and pediatric cardiology departments. Also, our study is one of the largest studies that has evaluated chest pain in children.

The serious and rare cardiac causes of pediatric chest pain, including anomalous coronary origins, cardiomyopathy, pulmonary hypertension, myocarditis, and pericarditis, can be diagnosed by history, cardiac examination, electrocardiogram, and echocardiogram. ${ }^{[1-8]}$ Previous retrospective ${ }^{[8,14,15]}$ and prospective ${ }^{[1-7]}$ studies reported a prevalence of cardiac abnormalities from 0 to $10 \%$. Similarly, our results emphasize the findings of previous reports showing that cardiac etiologies of pediatric chest pain are rare. The incidence of cardiac causes

\begin{tabular}{|c|c|c|c|c|}
\hline & \multicolumn{2}{|c|}{ Gender } & \multicolumn{2}{|c|}{ Total } \\
\hline & Boys N (\%) & Girls N (\%) & $\mathbf{N}$ & $\%$ \\
\hline $\begin{array}{l}\text { Cardiac chest pain } \\
\text { Mitral valve prolapse } \\
\text { Hypertrophic cardiomyopathy } \\
\text { Bicuspid aortic valve and aortic stenosis } \\
\text { Pulmonary artery hypertension } \\
\text { Pericarditis }\end{array}$ & $\begin{array}{c}11(4) \\
3 \\
1 \\
4 \\
2 \\
1\end{array}$ & $\begin{array}{c}14(6.2) \\
12 \\
1 \\
1 \\
- \\
-\end{array}$ & $\begin{array}{l}25 \\
15 \\
2 \\
5 \\
2 \\
1\end{array}$ & 4.8 \\
\hline Non-cardiac chest pain & $267(96)$ & 211 (93.8) & 478 & \\
\hline Idiopathic chest pain & $107(38.5)$ & $91(40.4)$ & 198 & 95.2 \\
\hline Musculoskeletal disorders & $114(41)$ & $75(33.3)$ & 189 & 39,4 \\
\hline Costochondritis & 101 & 66 & 167 & 37,6 \\
\hline Chest wall strain & 11 & 8 & 19 & \\
\hline Trauma & 2 & 1 & 3 & \\
\hline Respiratory disorders & $15(5.4)$ & $20(8.9)$ & 35 & \\
\hline Cough & 7 & 15 & 22 & 7 \\
\hline Pneumonia & 5 & 4 & 9 & \\
\hline Asthma & 3 & 1 & 4 & \\
\hline Gastrointestinal disorders & $14(5)$ & $15(6.7)$ & 29 & \\
\hline Gastroesophageal reflux & 11 & 10 & 21 & 5,8 \\
\hline Gastritis & 3 & 5 & 8 & \\
\hline Psychological disorders & $14(5)$ & $10(4.4)$ & 24 & \\
\hline Others & $3(1.1)$ & 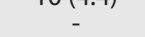 & 3 & 4,8 \\
\hline Familial Mediterranean Fever & 1 & - & 1 & 0,6 \\
\hline Gynaecomastia & 2 & - & 2 & \\
\hline
\end{tabular}

Table 3. The etiology of recurrent chest pain in study population.

\begin{tabular}{lcccc} 
& \multicolumn{2}{c}{ Chest pain without recurrence } & \multicolumn{2}{c}{ Recurrent chest pain } \\
\cline { 2 - 5 } & Boy N(\%) & Girl N(\%) & Boy N(\%) & Girl N(\%) \\
\hline Cardiac chest pain & $1(0.7)$ & $1(0.8)$ & $10(7.6)$ & $13(12.6)$ \\
Non-cardiac chest pain & & & $29(22)$ & $23(22.3)$ \\
$\quad$ Idiopathic chest pain & $78(53.4)$ & $68(55,7)$ & $57(43.2)$ & $10(35)$ \\
$\quad$ Musculoskeletal disorders & $57(39)$ & $6(32)$ & $13(9.8)$ & $14(13.6)$ \\
Respiratory disorders & $5(3.4)$ & $5(4.1)$ & $10(7.6)$ & $7(6.7)$ \\
Gastrointestinal disorders & $1(0.7)$ & $3(2.5)$ & $3(2.3)$ & - \\
Psychological disorders & $4(2.7)$ & - & & $7(6.8)$ \\
Others & - & & & - \\
\hline
\end{tabular}


of chest pain was $4.8 \%$ in our study. Also, we found that mitral valve prolapse was the most common etiology in cardiac chest pain group and it was diagnosed in girls more than boys. It is known that, mitral valve prolapsed may cause chest pain by papillary muscle or left ventricular endocardial ischemia. ${ }^{[2,3]}$

A follow-up study of 149 children presenting with chest pain showed recurrence with $43 \%$ and the majority of these cases were diagnosed as idiopathic chest pain. ${ }^{[6]}$ In another study, $16 \%$ of children with chest pain had more than one visit to the emergency department with the same complaint and $8 \%$ of them had chest pain for more than 1 year. ${ }^{[14]}$ Similarly, Sert et al. ${ }^{[5]}$ reported that, in their series chest pain had lasted for more than 6 months in 32.9\% of the children and approximately 5\% of children with chest pain had more than one visit.In our study, we reported that, $92 \%$ of patients with cardiac chest pain and $44.3 \%$ of patients with non-cardiac chest pain had recurrences. So, recurrent chest pain was found to be higher in cardiac chest pain group in our study population. Also, $48 \%$ of patients in cardiac chest pain group and $21.1 \%$ of patients in non-cardiac chest pain group had more than one visit to our pediatrics and pediatric cardiology departments with the same complaint.

As in previous studies, idiopathic chest pain and musculoskeletal disorders are the main cause of non-cardiac chest pain in the pediatric age. ${ }^{[1-8,14-17]}$ Idiopathic chest pain is diagnosed when no clear etiology can be found. In some studies, it was suggested that in $20-45 \%$ of cases with pediatric chest pain, no clear etiology can be found. ${ }^{[1,5,17]}$ On the other hand, musculoskeletal disorders are also common causes of chest pain in children and careful physical examination reveals chest wall tenderness or pain with movement of the torso or upper extremities. ${ }^{[1-8]}$ Costochondritis, chest wall strain and trauma are common causes of musculoskeletal disorders in children. ${ }^{[3-5]}$ Similarly in our study, we reported the incidence of chest pain related with idiopathic and musculoskeletal system disorders as $39.4 \%$ and $37.6 \%$, respectively. Also, we found that costochondritis was the major causes of musculoskeletal disorders in non-cardiac chest pain group.

Obesity is a growing problem around the world and it became an important etiology for chest pain on its own or in combination with other conditions in children and adults. ${ }^{[18]}$ So, another potential reason that more children with chest pain are being referred to pediatric cardiology is the increased number of overweight and obese children. It is possible that with increasing concern for premature coronary disease in overweight children. Also, their effort capacity is lower than the healthy population. In our study, 37 patients (7.3\%) in noncardiac chest pain group had obesity and 21 patients (4.1\%) were overweight.

School absenteeism is a specific marker of psychological distress and should always be investigated and emphasized with studies showing that it is a specific feature of children affected by somatic symptom disorders or other psychopathologies. ${ }^{[19]}$ It should also be considered that in such a frequent non-severe disease, as chest pain is, parental concerns more than child's fear may influence the quality of life of the child. Moreover, parents' catastrophist and hyper-protective attitudes are also a well-known risk factor for the development of children's somatic symptom disorder. Such studies revealed the incidence of psychogenic disturbances as $10.7 \%-74 \% .{ }^{[5,7]}$ In our study, we reported the incidence of psychological disorders as $4.8 \%$ (and it was more common in boys.

In our study, we found the referral incidence of patients with chest pain from the pediatrics departments to pediatric cardiology department as higher as $68.7 \%$. This may be because of parental concerns that are more than child's fear, dramatic media news about sudden deaths in young athletes and adolescents, family history of cardiac diseases and families' own wills for referral to pediatric cardiology departments. However, despite all these reasons, high referral rates increase the unnecessary inspection rate and increase the cost.

\section{CONCLUSION}

Chest pain is a common referral complaint in children. In this study, the most common etiologies of chest pain in children were idiopathic chest pain and musculoskeletal disorders. Although, our results showed that chest pain is commonly recurrent and cardiac causes of chest pain are very rare in children. So, unnecessary referrals should be reduced with a careful history and physical examination. We suggest that echocardiography may not be necessary for the routine evaluation of children with chest pain with a weighted use of the resources to contain the health costs.

\section{ETHICAL DECLARATIONS}

Ethics Committee Approval: This is a retrospective study. The authors assert that all procedures contributing to this work comply with the ethical standards of the relevant national guidelines on human experimentation of Turkish Ethical Guidelines and with the Helsinki Declaration of 1975, as revised in 2008. Also, to screen the files retrospectively, written consent was obtained from the head physician of the hospital's committee. (T.C. Ministry Health Konya Provincial Health Directorate Dr. Ali Kemal Belviranli Obstetrics And Pediatrics Hospital date 2020 numbered 99980113-903.99).

Informed Consent: Because the study was designed retrospectively, no written informed consent form was obtained from patients.

Referee Evaluation Process: Externally peer-reviewed. Conflict of Interest Statement: The authors have no conflicts of interest to declare.

Financial Disclosure: The authors declared that this study has received no financial support.

Author Contributions:Concept:E.K.A., H.A.Design:E.K.A.Data Collection or Processing: E.K.A., H.A. Analysis or Interpretation: H.A. Literature Search: E.K.A., H.A. Writing: E.K.A. 


\section{REFERENCES}

1. Selbst SM, Ruddy RM, Clark BJ. Pediatric chest pain: a prospective study. Pediatrics 1988;82(3):319-23.

2. Ives A Daubeney PE, Balfour-Lynn IM. Recurrent chest pain in the well child. Arch Dis Child 2010;95(8):649-54.

3. Geggel RL. Conditions leading to pediatric cardiology consultation in a tertiary academic hospital. Pediatrics 2004;114(4):e409-17.

4. Cava JR, Sayger PL. Chest pain in children and adolescents. Pediatr Clin North Am 2004;51(6):1553-68.

5. Sert A, Aypar E, Odabas D, Gokcen C. Clinical characteristics and causes of chest pain in 380 children referred to a paediatric cardiology unit. Cardiol Young 2013;23(3):361-7.

6. Selbst SM, Ruddy R, Clark BJ. Chest pain in children. Follow-up of patients previously reported. Clin Pediatr 1990;29(7):374-7.

7. Tunaoglu FS, Olguntürk R, Akcabay S, Oguz D, Gücüyener K, Demirsoy S. Chest pain in children referred to a cardiology clinic. Pediatr Cardiol 1995; 16(2):69-72.

8. Fukushige J, Tsuchihashi K, Harada T, Ueda K. Chest Pain in Pediatric Patients. Pediatr Int 1988;30(5):604-7.

9. Verghese GR, Friedman KG, Rathod RH, et al. Resource utilization reduction for evaluation of chest pain in pediatrics using a novel Standardized Clinical Assessment and Management Plan (SCAMP). J Am Heart Assoc 2012;1(2):pii: jah3-e000349.

10. Friedman KG, Kane DA, Rathod RH, et al. Management of pediatric chest pain using a standardized assessment and management plan. Pediatrics 2011;128(2):239-45.

11. Kane DA, Friedman KG, Fulton DR, Geggel RL, Saleeb SF. Needles in hay II: detecting cardiac pathology by the pediatric chest pain standardized clinical assessment and management plan. Congenit Heart Dis 2016;11(5):396-402.

12. Daniels SR, Greer FR. Committee on nutrition. Lipid screening and cardiovascular health in childhood. Pediatrics 2008;122(1):198-208.

13. Lopez L, Colan SD, Frommelt PC, et al. Recommendations for quantification methods during the performance of a pediatric echocardiogram: a report from the Pediatric Measurements Writing Group of the American Society of Echocardiography Pediatric and Congenital Heart Disease Council. J Am Soc Echocardiogr 2010;23(5):465-95.

14. Selbst SM. Chest pain in children. Pediatrics 1985;75(6):1068-70.

15. Zavaras-Angelidou, KA Weinhouse E, Nelson DB. Review of 180 episodes of chest pain in 134 children. Pediatr Emerg Care 1992;8(4):189-93.

16. Massin MM, Bourguignont A, Coremans C, Comté L, Lepage $P$, Gérard P. Chest pain in pediatric patients presenting to an emergency department or to a cardiac clinic. Clin Pediatr (Phila) 2004;43(3):231-8.

17. Driscoll DJ, Glicklich LB, Gallen WJ. Chest pain in children: a prospective study. Pediatrics 1976;57(5):648-51.

18. Peitz GW, Troyer J, Jones AE, et al. Association of body mass index with increased cost of care and length of stay for emergency department patients with chest pain and dyspnea. Circ Cardiovasc Qual Outcomes 2014;7(2):292-8.

19. Cozzi G, Minute $M$, Skabar A, et al. Somatic symptom disorder was common in children and adolescents attending an emergency department complaining of pain. Acta Paediatr 2017;106(4):586-93. 